\title{
GAMMA IRRADIATION IN THE CONTROL OF PATHOGENIC BACTERIA IN REFRIGERATED GROUND CHICKEN MEAT
}

\author{
Marta Helena Filet Spoto ${ }^{1,3}$; Cláudio Rosa Gallo2; André Ricardo Alcarde1,3*; Maria Sílvia do \\ Amaral Gurgel ${ }^{1,3}$; Lucimara Blumer ${ }^{1}$; Júlio Marcos Melges Walder ${ }^{1}$; Rachel Elisabeth Domarco ${ }^{1}$ \\ ${ }^{1}$ Lab. de Irradiação de Alimentos e Radioentomologia - USP/CENA, C.P. 96 - CEP: 13400-970 - Piracicaba, SP. \\ ${ }^{2}$ Depto. de Agroindústria, Alimentos e Nutrição - USP/ESALQ, C.P. 9 - CEP: 13418-900 - Piracicaba, SP. \\ ${ }^{3}$ Bolsista FAPESP. \\ ${ }^{*}$ Corresponding author <aalcarde@cena.usp.br>
}

\begin{abstract}
This work evaluated the effect of gamma radiation on reducting the population of Staphylococcus aureus, Escherichia coli and Salmonella typhimurium in ground chicken breast stored under refrigeration. The experiment included a control and 4 doses of gamma radiation (2.0, 4.0, 6.0 and 8.0 kGy) along with 5 periods of storage under refrigeration (1, 7, 14, 21 and 28 days). Samples of ground chicken breast were inoculated with Staphylococcus aureus (ATCC 14458), Escherichia coli (ATCC 11105) and Salmonella typhimurium (ATCC 0626), irradiated at temperatures between 4 and $8^{\circ} \mathrm{C}$ and stored under refrigeration $\left(5^{\circ} \mathrm{C}\right)$ for 28 days. The increased radiation dose and period of storage under refrigeration caused a reduction of Staphylococcus aureus, Escherichia coli and Salmonella typhimurium populations in the ground chicken breast. Mean radiation $D$ values determined for Staphylococcus aureus and Escherichia coli were 0.41 and 0.72 kGy, respectively. Gamma irradiation was an effective treatment for chicken meat conservation because the radiation dose of $6.0 \mathrm{kGy}$ kept the ground chicken breast within the microbiological limits established by the Brazilian legislation, for up to 28 days under refrigeration.

Key words: gamma irradiation, pathogenic bacteria, chicken meat, refrigeration
\end{abstract}

\section{IRRADIAÇÃO GAMA NO CONTROLE DE BACTÉRIAS PATOGÊNICAS EM CARNE DE FRANGO REFRIGERADA}

\begin{abstract}
RESUMO: Este trabalho avaliou a capacidade da radiação gama em reduzir a população das bactérias Staphylococcus aureus, Escherichia colie Salmonella typhimurium em peito de frango moído armazenado sob refrigeração. O experimento consistiu do controle e 4 doses de radiação gama (2,0; 4,0; 6,0 e 8,0 kGy), durante 5 períodos de armazenamento sob refrigeração (1,7,14,21 e 28 dias). As amostras de peito de frango moído foram inoculadas com Staphylococcus aureus (ATCC 14458), Escherichia coli (ATCC 11105) e Salmonella typhimurium (ATCC 0626), irradiadas em temperaturas entre 4 e $8^{\circ} \mathrm{C}$ e armazenadas sob refrigeração $\left(5^{\circ} \mathrm{C}\right)$ por 28 dias. As maiores doses de radiação e os períodos mais longos de armazenamento sob refrigeração causaram uma redução nas populações de Staphylococcus aureus, Escherichia colie Salmonella typhimurium do peito de frango. A média dos valores D de radiação determinados para Staphylococcus aureus e Escherichia coli foram 0,41 e 0,72 kGy, respectivamente. A irradiação gama foi um eficiente tratamento para a conservação da carne de frango porque a dose de radiação de 6,0 kGy manteve o peito de frango moído dentro dos limites microbiológicos estabelecidos pela legislação brasileira por até 28 dias sob refrigeração.

Palavras-chave: irradiação gama, bactéria patogênica, carne de frango, refrigeração
\end{abstract}

\section{INTRODUCTION}

Despite substantial efforts to avoid contamination, an upward trend in the number of outbreaks of foodborne diseases caused by nonsporeforming pathogenic bacteria are reported in many countries.

Authough several decontamination methods exist, one of the most versatile treatment among them is the processing of foods with ionizing radiation. Decontamination of food by ionizing radiation is a safe, efficient, environmentally clean and energy efficient process.

Radiation treatment with doses of 2.0-7.0 kGy, depending on the condition of irradiation, initial contamination and the type of food, can effectively eliminate potentially pathogenic nonsporeforming bacteria including both long-time recognized pathogens such as Salmonella and Staphylococcus aureus as well as emerging or "new" pathogens such as Campylobacter, Listeria monocytogenes or Escherichia coli O157:H7 from suspected food products .

Candidates to radiation decontamination are mainly poultry and red meat, egg products, and fishery products. With today's demand for high-quality convenience foods, irradiation in combination with other processes holds a promise for enhancing the safety of many minimally processed foods (Farkas, 1998). These products are still incipients in Brazilian market but in a near future they might fill a considerable part of the market because of the advantages of the low-processed foods.

This experimental work evaluated the sensitivity of Staphylococcus aureus (ATCC 14458), Escherichia coli 
(ATCC 11105) and Salmonella typhimurium (ATCC 0626) to gamma radiation in ground chicken breast stored under refrigeration. This work also established the radiation $\mathrm{D}$ values for reducing Staphylococcus aureus and Escherichia coli in the food.

\section{MATERIAL AND METHODS}

The lyophilized cultures of Staphylococcus aureus (ATCC 14458), Escherichia coli (ATCC 11105) and Salmonella typhimurium (ATCC 0626) were originally obtained from ATCC by the Fundação Oswaldo Cruz of the Instituto Nacional de Controle de Qualidade em Saúde, located in São Paulo-SP, Brazil. The cultures of Staphylococcus aureus and Escherichia coli were reactived separately in BHI (Brain Heart Infusion) and the culture of Salmonella typhimurium was reactived in nutrient broth, all held at $35-37^{\circ} \mathrm{C}$ for 24 hours. Following, the cultures were inoculated again into the respective medium and incubated at $35-37^{\circ} \mathrm{C}$ for 24 hours. These culture suspensions containing approximmately $10^{6} \mathrm{CFU} \mathrm{mL}^{-1}$ of Staphylococcus aureus, $10^{6} \mathrm{CFU} \mathrm{mL}^{-1}$ of Escherichia coli

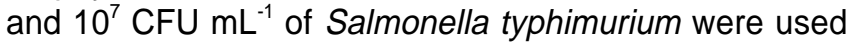
to contaminate the samples.

The chicken breasts were obtained from chicken slaughtered in the city of Rio Claro/SP at the same day of the irradiation. The chicken breasts were kept refrigerated until they were ground in a food-processor. Each $500 \mathrm{~g}$ of ground chicken breast were mixtured in the food-processor with $10 \mathrm{~mL}$ of each culture suspension. Samples of $50 \mathrm{~g}$ of ground chicken breast were accomodated in petri plates, packed with parafilm and irradiated.

The samples were irradiated with doses of 2.0, 4.0, 6.0 and $8.0 \mathrm{kGy}$ at a rate of $0.929 \mathrm{kGy} \mathrm{h}^{-1}$. The gamma rays came from a panoramic source of ${ }^{60} \mathrm{Cobalt}$, with activity of $2,000 \mathrm{Ci}$, located in the Centro de Energia Nuclear na Agricultura - Universidade de São Paulo in Piracicaba-SP. During the irradiation the temperature of the samples was kept between 4 and $8^{\circ} \mathrm{C}$ using dry ice. The control of the dose of radiation absorbed by the samples was made using polimethylmetacrilat dosimeters. After irradiation the samples were stored under refrigeration $\left(5^{\circ} \mathrm{C}\right)$ for $1,7,14,21$ and 28 days of storage. Individual petri plates of chicken meat were withdrawn at each sampling period and 25 grams of the sample were assayed for each microbiological analysis. The mimimum detection level for the plate counts was 1 CFU (colony forming unit) per plate.

The count of Staphylococcus aureus was accomplished in selective medium BPA (Baird-Parker-Agar) and $\mathrm{BHI}$, incubated at $35^{\circ} \mathrm{C}$ for 48 hours (Vanderzant \& Splittstroesser, 1992). The count of Escherichia coli population was accomplished in petrifilm plates incubated at $42^{\circ} \mathrm{C}$ for 48 hours. The detection of Salmonella typhimurium was accomplished, after enrichment in nutrient broth at $35-37^{\circ} \mathrm{C}$ for 24 hours, using the kit Salmonella Rapid Test (Oxoid) held at $41^{\circ} \mathrm{C}$ for 24 hours.
The experimental design was a $5 \times 5$ factorial scheme, including a control and 4 doses of gamma radiation $(2.0 ; 4.0 ; 6.0$ and $8.0 \mathrm{kGy})$ along with 5 periods of storage under refrigeration $(1,7,14,21$ e 28 days), with 3 replicates in each treatment.

Results were submitted to Variance analysis, Hartley test, $F$ test $(p<0.05)$ and polinomial regression analyses $(\alpha=0.05)$ using the software SAS-Statistic.

\section{RESULTS AND DISCUSSION}

\section{Staphylococcus aureus}

At all periods of storage under refrigeration, the increased of the dose of radiation caused reduction on Staphylococcus aureus population in ground chicken breast (Figure 1). The dose of $2.0 \mathrm{kGy}$ reduced Staphylococcus aureus population in aproximmately 4 logarithmic cycles (from $10^{7}$ to $10^{3} \mathrm{CFU} \mathrm{g}{ }^{-1}$ ). The dose of $4.0 \mathrm{kGy}$ reduced Staphylococcus aureus population in aproximmately 6 logarithmic cycles (from $10^{7}$ to $10^{1} \mathrm{CFU} \mathrm{g}^{-1}$ ). Colonies of Staphylococcus aureus were not detected in the samples irradiated with 6.0 and $8.0 \mathrm{kGy}$.

Staphylococcus aureus population remained between $10^{7}$ and $10^{8} \mathrm{CFU} \mathrm{g}^{-1}$ during the period of storage of the control samples. The samples irradiated with $2.0 \mathrm{kGy}$ showed Staphylococcus aureus population between $10^{3}$ and $10^{4} \mathrm{CFU} \mathrm{g}{ }^{-1}$ during the period of storage. Staphylococcus aureus populations between $10^{1}$ and $10^{2}$ CFU ${ }^{-1}$ were observed during the period of storage of the ground chicken breast irradiated with $4.0 \mathrm{kGy}$ (Figure 2).

The results of this research concerned the reduction of Staphylococcus aureus population in irradiated chicken meat are similar to those found by some authors. Thayer \& Boyd (1992) didn't find viable CFU of Staphylococcus aureus in mechanically deboned chicken meat inoculated with $8.0 \times 10^{3} \mathrm{CFU} \mathrm{g}{ }^{-1}$ of Staphylococcus aureus ATCC 13565 and irradiated with $1.50 \mathrm{kGy}$. However, these authors refers to the dose of $3.0 \mathrm{kGy}$ as

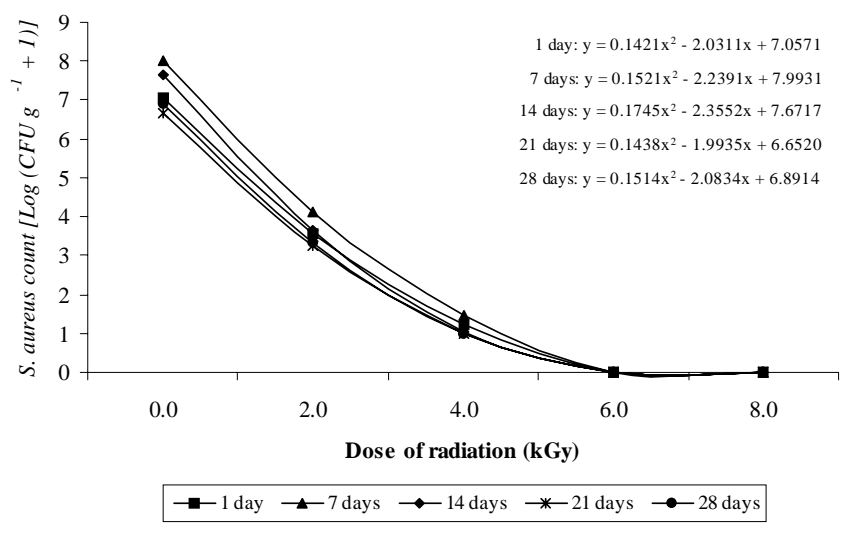

Figure 1 - Effect of gamma radiation on the reduction of Staphylococcus aureus population in ground chicken breast stored under refrigeration. 


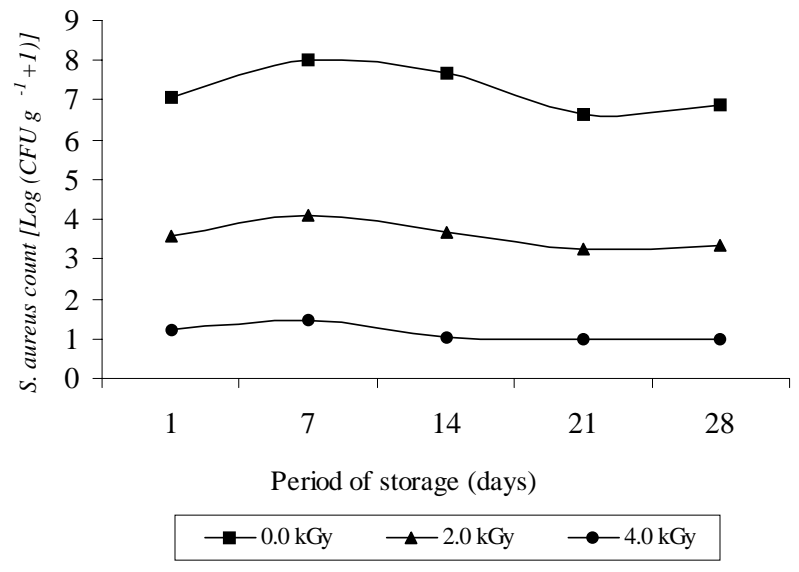

Figure 2 - Variation of Staphylococcus aureus population during the period of storage under refrigeration of irradiated ground chicken breast.

minimum for consumer's protection against foodborne disease caused by Staphylococcus aureus in that product. Nouchpramool et al. (1985) observed that the dose of radiation of $3.0 \mathrm{kGy}$ was able to eliminate Staphylococcus aureus in frozen shrimp. The dose of 2.5 kGy was able to eliminate Staphylococcus aureus in smoked fish (Research, 1978). However, Kolsarici \& Kirimca (1995) verified that Staphylococcus were resistant to doses of radiation up to $3.0 \mathrm{kGy}$ in chicken meat.

Klinger et al. (1986) observed reduction of 2 logarithmic cycles in Salmonella, Staphylococcus and coliforms populations in chicken carcasses irradiated with $4.5 \mathrm{kGy}$. The authors mentioned the dose of $7.0 \mathrm{kGy}$ as efficient in the decontamination of the product.

Idziak \& Incze (1968) observed that doses of radiation from 5.0 to $7.0 \mathrm{kGy}$ promoted reduction of 11 logarithmic cycles in Staphylococcus aureus count in chicken carcasses.

Thayer et al. (1997) concluded that Staphylococcus aureus can be eliminated or greatly reduced in number in bison, ostrich, alligator and caiman meats by doses of gamma radiation between 1.5 and 3.0 kGy and storage at $5^{\circ} \mathrm{C}$.

According to Thayer (1995) low doses of ionizing radiation $(<3.0 \mathrm{kGy})$ may eliminate or significantly decrease the population of the most common enteric pathogens such as Campylobacter jejuni, Escherichia coli, Staphylococcus aureus, Salmonella spp., Listeria monocytogenes and Aeromonas hydrophila. Ionizing radiation can be an effective step in a program to kill enteric pathogens associated with meat and poultry products.

Mean radiation $D$ value (dose of radiation to decrease the microorganism population in 1 logarithmic cycle) determined for Staphylococcus aureus in refrigerated ground chicken breast was $0.41 \mathrm{kGy}$ (TABLE 1). This result was similar to those reported by some researchers. Thayer et al. (1997) obtained radiation D value of $0.37 \mathrm{kGy}$ for Staphylococcus aureus in high-value meats irradiated at
TABLE 1 - Linear equations for Staphylococcus aureus reduction in irradiated ground chicken breast and the radiation $D$ value for each period of storage under refrigeration.

\begin{tabular}{ccc}
\hline $\begin{array}{c}\text { Period of } \\
\text { storage }\end{array}$ & $\begin{array}{c}\text { Linear equation } \\
(y=\log (\text { CFU g-1 }+1) ; x=k G y)\end{array}$ & $\begin{array}{c}\text { Radiation } D \\
\text { value }\end{array}$ \\
\hline (days) & & (kGy) \\
1 & $y=-2.353 x+8.84$ & 0.42 \\
7 & $y=-2.662 x+10.05$ & 0.38 \\
14 & $y=-2.563 x+9.50$ & 0.39 \\
21 & $y=-2.221 x+8.27$ & 0.45 \\
28 & $y=-2.302 x+8.56$ & 0.43 \\
\hline Average & & 0.41 \\
\hline
\end{tabular}

$5^{\circ} \mathrm{C}$. Hau et al. (1992) found radiation D value of $0.29 \mathrm{kGy}$ for Staphylococcus aureus in frozen shrimp. Grant \& Patterson (1992) reported radiation $D$ values for Staphylococcus aureus between 0.25-0.43 kGy in several kinds of food. Josephson (1983) reported radiation D value of $0.46 \mathrm{kGy}$ for Staphylococcus aureus in nutrient broth, but in seafood this author reported values between 0.8 and $1.9 \mathrm{kGy}$ for the bacteria.

\section{Escherichia coli}

The number of Escherichia coli colonies decreased with the increased of the dose of radiation and the increased of the period of storage under refrigeration.

The dose of $6.0 \mathrm{kGy}$ was required to inhibit Escherichia coli growth in the samples at 1 and 7 days of refrigerated storage. At 14, 21 and 28 days of storage, the dose of 4.0 was enough to inhibit bacteria growth in the samples (Figure 3).

The samples irradiated with 2.0 kGy showed an approximated reduction of 3 logarithmic cycles on Escherichia coli population in relation to the control. The dose of $4.0 \mathrm{kGy}$ reduced approximately 6 logarithmic cycles the Escherichia coli count. The doses of 6.0 and $8.0 \mathrm{kGy}$ reduced Escherichia coli population below the detectable level (Figure 3).

Escherichia coli population decreased approximately 2 logarithmic cycles during the period of storage of the control samples (from $10^{8}$ to $10^{6} \mathrm{CFU} \mathrm{g}^{-1}$ ). The samples irradiated with $2.0 \mathrm{kGy}$ also showed reduction of 2 logarithmic cycles on Escherichia coli population during the period of storage (from $10^{4}$ to $10^{2} \mathrm{CFU} \mathrm{g}{ }^{-1}$ ). The samples irradiated with $4.0 \mathrm{kGy}$ showed Escherichia coli population of $10^{1} \mathrm{CFU} \mathrm{g}^{-1}$ at 1 day of storage and colonies were not detected just at 14 days of refrigerated storage of the ground chicken breast (Figure 4).

The results found in this work concerned the reduction of Escherichia coli count in irradiated chicken meat are similar to those obtained by Bánáti et al. (1993) who reported that dose of $2.0 \mathrm{kGy}$ reduced 4 logarithmic cycles the Escherichia coli population in irradiated chicken meat. Still according to these authors, at low levels of 


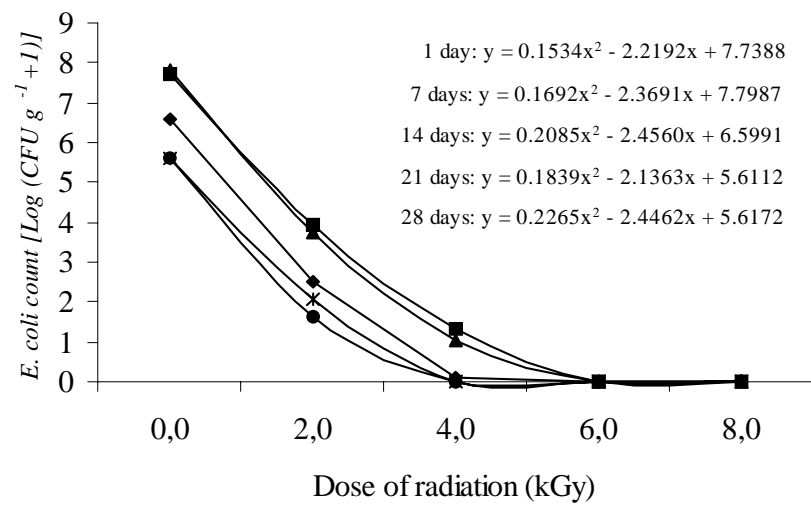

$\multimap-1$ day $\multimap 7$ days $\multimap 14$ days $\rightarrow-21$ days $\multimap 28$ days

Figure 3 - Effect of gamma radiation on the reduction of Escherichia coli population in ground chicken breast stored under refrigeration.

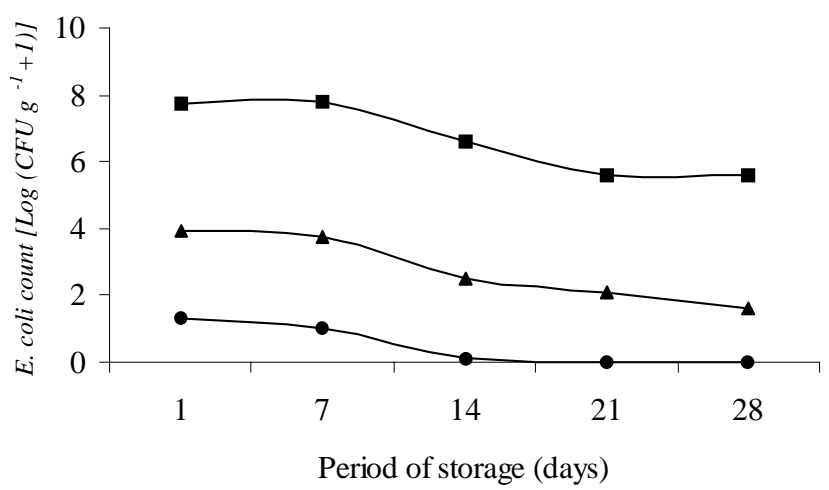

$\multimap-0.0 \mathrm{kGy} \multimap 2.0 \mathrm{kGy} \multimap 4.0 \mathrm{kGy}$

Figure 4 - Variation of Escherichia coli population during the period of storage under refrigeration of irradiated ground breast chicken.

contamination, the dose of $2.0 \mathrm{kGy}$ is enough to inactivate most of the nonsporeforming bacteria in meats but, when the contamination exceeds $10^{6} \mathrm{CFU} \mathrm{g}{ }^{-1}$, higher doses of radiation are required to reduce the bacteria to acceptable counts.

Lescano et al. (1991) did not detect Escherichia coli in chicken meat irradiated with $2.5 \mathrm{kGy}$. However, the dose of $4.0 \mathrm{kGy}$ was necessary to inactivate Escherichia coli in extracts of refrigerated fish (Viana, 1993).

Mean radiation D value determined for Escherichia coli in refrigerated ground chicken breast was $0.72 \mathrm{kGy}$ (TABLE 2). This value was higher than those reported by some authors. According to Urbain (1986) the radiation D value for Escherichia coli varies from 0.20 to $0.40 \mathrm{kGy}$ in phosphate solution. The same values were found in irradiated red meats and poultry stored under refrigeration (Farkas, 1987; Patterson, 1988; Thayer, 1993 and Tsuji, 1983). In frozen meats the value reported is $0.55 \mathrm{kGy}$ (Farkas, 1987).
TABLE 2 - Linear equations for Escherichia coli reduction in irradiated ground chicken breast and the radiation $D$ value for each period of storage under refrigeration.

\begin{tabular}{ccc}
\hline $\begin{array}{c}\text { Period of } \\
\text { storage }\end{array}$ & Linear equation & $\begin{array}{c}\text { Radiation } D \\
\text { value }\end{array}$ \\
\hline (days) & $\left(y=\log \left(C F U g^{-1}+1\right) ; x=k G y\right)$ & $(k G y)$ \\
1 & $y=-1.296 x+7.11$ & 0.77 \\
7 & $y=-1.306 x+7.06$ & 0.77 \\
14 & $y=-1.623 x+6.32$ & 0.62 \\
21 & $y=-1.403 x+5.37$ & 0.71 \\
28 & $y=-1.405 x+5.23$ & 0.71 \\
\hline Average & & 0.72 \\
\hline
\end{tabular}

\section{Salmonella typhimurium}

The resistance of Salmonella typhimurium to gamma radiation decreased with the increased of the dose of radiation and the increased of the period of storage under refrigeration (TABLE 3). The control samples presented bacterial activity at all the periods of storage under refrigeration and the irradiated samples showed interaction between gamma radiation and refrigeration on the reduction of Salmonella typhimurium population. The dose of $2.0 \mathrm{kGy}$ inhibited bacterial activity from 21 days of storage. The dose of $4.0 \mathrm{kGy}$ was able to inhibited bacterial activity from 7 days of storage. Bacterial activity was not detected in the samples irradiated with 6.0 and $8.0 \mathrm{kGy}$ just at 1 day of storage. During all the period of storage under refrigeration, bacterial activity was not observed in the samples irradiated with 6.0 and $8.0 \mathrm{kGy}$.

The control samples and the samples irradiated with $2.0 \mathrm{kGy}$ presented bad odour from 7 days of storage. From 21 days of storage, these samples had a rotten appearance and brownish coloration. The samples irradiated with 4.0, 6.0 and 8.0 kGy did not present bad smell or rotten appearance in any of the periods of storage.

The results of this work are similar to those reported by some authors who have observed that $2.5 \mathrm{kGy}$ is an efficient dose of radiation to inhibit the growth of Salmonella and increase the shelflife of refrigerated chicken meat (Thayer \& Boyd, 1992; Lescano et al., 1991; Lamuka et al., 1992). Similar results were observed by Hanis et al. (1989) who concluded that, despite this dose of radiation is not enough to promote pasteurization of the product, the microorganisms are greatly affected by the interaction between radiation and refrigeration.

In the literature there is not a consent about the dose of radiation to control Salmonella in chicken meats. According to USDA (1992) and Morrison et al. (1992) doses of 1.5 to $3.0 \mathrm{kGy}$ can eliminate 99,5 to $99,9 \%$ of Salmonella population in poultry. Other authors affirm that higher doses of radiation are necessary to inhibit Salmonella and assure a product stable and healthy in a sanitary and microbiological point of view. Farkas (1987), Döllstädt et al. (1990) and Viana (1993) reported that doses 
TABLE 3 - Detection of Salmonella typhimurium in irradiated ground chicken breast stored under refrigeration.

\begin{tabular}{cccccc}
\hline $\begin{array}{c}\text { Period of } \\
\text { storage }\end{array}$ & \multicolumn{5}{c}{ Dose of radiation (kGy) } \\
\cline { 2 - 6 } (days) & 0.0 & 2.0 & 4.0 & 6.0 & 8.0 \\
\hline 1 & + & + & + & - & - \\
7 & + & + & - & - & - \\
14 & + & + & - & - & - \\
21 & + & - & - & - & - \\
28 & + & - & - & - & - \\
\hline
\end{tabular}

$+:$ bacterial activity detected in at least one of the replicates

-: bacterial activity detected in none replicate

between 3.0 and $5.0 \mathrm{kGy}$ could inactivate the nonsporeforming bacteria from meats, poultry and fish. Patterson (1988) affirmed that doses between 5.0 to 7.0 kGy are effective to inactivate Salmonella in several kinds of meat.

Idziak \& Incze (1968) observed that the dose of $5.0 \mathrm{kGy}$ reduced the number of viable colonies of Salmonella in chicken carcasses, which could be conserved for 20 days under refrigeration. However, Hanis et al. (1989) observed that the dose of $5.0 \mathrm{kGy}$ was not enough to eliminate Salmonella typhimurium in refrigerated chicken but no bacteria of that species was detected in the meat irradiated with $10.0 \mathrm{kGy}$.

According to Silva et al. (1997), the anexx I of the Edict n. 01/1987 of the Divisão Nacional de Vigilância Sanitária de Alimentos of the Secretaria Nacional de Vigilância Sanitária establishes the absence of Salmonella in $25 \mathrm{~g}$ of the product as the microbiological specific pattern for chicken meat. Nevertheless, this Edict does not present microbiological specific patterns or limits to any other microorganism.

The anexx II of the same Edict, concerning the microbiological limits for the analysis of foods for which specific patterns do not exist, establishes as acceptable for human consumption the product that presents up to $10^{3}$ of Staphylococcus aureus for $\mathrm{g}$ or $\mathrm{mL}$, up to $10^{2}$ of faecal coliforms for $\mathrm{g}$ or $\mathrm{mL}$ and the absence of Salmonella in 25 $\mathrm{g}$ or $\mathrm{mL}$.

The samples irradiated with $4.0 \mathrm{kGy}$ presented counts of $10^{1} \mathrm{CFU} \mathrm{g}{ }^{-1}$ of Staphylococcus aureus (Figure 1) and counts between $10^{\circ}$ and $10^{1} \mathrm{CFU} \mathrm{g}{ }^{-1}$ of Escherichia coli (Figure 3), what placed these samples within the microbiological limits established by the Brazilian legislation. Besides, these bacteria are mesophilic pathogens that do not usually grow in temperature of refrigeration, therefore, even if presenting few viable CFU, the infected product (presence of the pathogen) would not become infectant (pathogen in number to cause the disease) because these bacteria have to reach counts of $10^{6} \mathrm{CFU} \mathrm{g}^{-1}$ to cause alimentary toxinfection.

Salmonella typhimurium was not detected in the samples irradiated with $6.0 \mathrm{kGy}$ in any period of storage under refrigeration, placing these samples within the microbiological limits established by the Brazilian legislation. The dose of $4.0 \mathrm{kGy}$ only was able to inhibited this bacteria activity from 7 days of storage.

However, as negligences and inadequate refrigeration conditions and manipulation are often present in the preparation of foods, it should be considered the dose of $6.0 \mathrm{kGy}$ as a safety dose of radiation for the treatment of the product aiming its conservation. The dose of $6.0 \mathrm{kGy}$ was the minimum dose of radiation required for the complete inactivation of Staphylococcus aureus, Escherichia coli and Salmonella typhimurium in ground chicken breast stored under refrigeration.

\section{CONCLUSION}

Gamma irradiation was an effective treatment for chicken meat conservation because the radiation dose of 6.0 kGy kept the ground chicken breast within the microbiological limits established by the Brazilian legislation, for up to 28 days under refrigeration.

\section{ACKNOWLEDGEMENTS}

This work was performed while Marta H. F. Spoto was a Post-Doctoral Fellow of FAPESP, the "Foundation for Research Suport of the State of São Paulo". André R. Alcarde and Maria S. Amaral Gurgel were Doctoral Fellow of FAPESP.

\section{REFERENCES}

BÁNÁTI, D.; FIELDING, L.M.; GRANDINSON, A.S.; COOK, P.E. The effect of combinations of irradiation and $\mathrm{pH}$ on the survival of Escherichia coli on chicken meat. Letters in Applied Microbiology, v.16, p.239-242, 1993.

DÖLLSTÄDT, R.; GRAHN, C.; HÜBNER, G.; KÖHLER, B.; KRAUTSCHIK, J. Introdution of chicken irradiation on a industrial scale. Acta Alimentaria, v.19, p.107-124, 1990.

FARKAS, J. Decontamination, including parasite control, of dried, chilled and frozen foods by irradiation. Acta Alimentaria, v.16, p.351-384, 1987.

FARKAS, J. Irradiation as a method for decontaminating food: a review. International Journal of Food Microbiolology, v.44, p.189-204, 1998.

GRANT, I.R.; PATERSON, M.F. Sensitivity of foodborne pathogens to irradiation in the components of chilles ready meal. Food Microbiolology, v.9, p.95-103, 1992.

HANIS, T.; JELEN, P.; KLIR, P.; MINUKOVA, J.; PEREZ, B.; PESEK, M. Poultry meat irradiation - Effect of temperature on chemical changes and inativation of microrganisms. Journal of Food Protection, v.52, p.26-29, 1989.

HAU, L.B.; LIEW, M.H.; YET, L.T. Preservation of grass prawns by ionizing radiation. Journal of Food Protection, v.55, p.98-102, 1992.

IDZIAK, E.S.; INCZE, K. Radiation treatment of foods. Applied Microbiology, v.16, p.1061-1066, 1968.

JOSEPHSON E.S. Radappertization of meat. Poultry, finfish, shellfish and special diets. In: JOSEPHSON, E.S.; PETERSON M.S. (Ed.) Preservation of food by ionizing irradiation. New York: CRC Press, 1983. v.3, p.231-252. 
KLINGER, I.; FUCHS, V.; BASKER, D.; JUVEN, B.J.; LAPIDOT, M.; EISENBERG, E. Irradiation of broiler chicken meat. Israel Journal of Veterinary Medicine, v.42, p.181-192, 1986.

KOLSARICI, N.; KIRIMCA, G. Effect of radurization on microbiological. chemical and sensorial properties of chicken meats. Gida, v.20, p.67-73, 1995.

LAMUKA, P.O.; SUNKI, G.R.; CHAWAN, C.B.; RAO, D.R.; SHACKELFORD, L.A. Bacteriological quality of freshly processed broiler chickens as affected by carcass pretreatment and gamma irradiation. Journal of Food Science, v.57, p.330-332, 1992.

LESCANO, G.; NARVAIZ, P.; KAIRIYAMA, KAUPERT, N. Effect of chicken breast irradiation on microbiological, chemical and organoleptic quality. Lebensmittel-Wissenschaft und Technologie, v.24, p.130-134, 1991.

MORRISON, R.M.; ROBERTS, T.; WITUCKI, L. Irradiation of U.S. poultry: benefits, costs, and export potential. Food Review, v.15, p.16-21, 1992.

NOUCHPRAMOOL, K.; PUNGSILPA, S.; ADULYATHAM, P. Improvement of bacteriological quality of frozen shrimp by gamma radiation. Office of Atomic Energy for Peace, v.9, p.23, 1985.

PATTERSON, M. Sensitivity of bacteria to irradition on poultry irradiated under various atmospheres. Letters in Applied Microbiology, v.7, p.55-58, 1988.

RESEARCH COORDINATION MEETING WHOLESOMENESS OF FOOD IRRADIATION PROCESSING. Food Irradiation Information, v.9, p.128-133, 1978.

SILVA, N.; JUNQUEIRA, V.C.A.; SILVEIRA, N.F.A. Manual de métodos de análise microbiológica de alimentos. São Paulo: Livraria Varela, 1997. 295p.
THAYER, D.W. Use of irradiation to kill enteric pathogens on meat and poultry. Journal of Food Safety, v.15, p.181-192, 1995.

THAYER, D.W.; BOYD, G. Gamma ray processing to destroy Staphylococcus aureus in mechanically deboned chicken meat. Journal of Food Science, v.57, p.848-851, 1992.

THAYER, D.W.; BOYD, G. Elimination of Escherichia coli O157:H7 in meats by gamma irradiation. Applied and Environmental Microbiology, v.58, p.1030-1034, 1993.

THAYER, D.W.; BOYD, G.; FOX, J.B.J.R.; LAKRITZ, L. Elimination by gamma irradiation of Salmonella spp. and strains of Staphylococcus aureus inoculated in bison, ostrich, alligator, and caiman meat. Journal of Food Protection, v.60, p.756-760, 1997.

TSUJI, K. Low-dose cobalt 60 irradiation for reduction of microbial contamination in raw materials for animal health products. Food Technology, v.37, p.48-54, 1983.

URBAIN, W.M. Food irradiation. Orlando: Academic Press, 1986. 351p.

USDA. Poultry irradiation and preserventing foodborne illness. Washington: USDA, FSIS Backgrounder, Food Safety and Inspection Service, 1992. 1-6p.

VANDERZANT, C.; SPLITTSTROESSER, D.F. Compendium of methods for the microbiological examination of foods. 3.ed. Washington: American Public Health Association, 1992. 1219p.

VIANA, C.M. Estudo bacteriológico de extrato de pescado refrigerado submetido à radiação gama. Niterói, 1993. 49p. Tese (Doutorado) - Universidade Federal Fluminense.

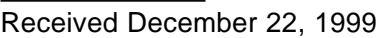

